\title{
Cultural optimization and metal effects of Shewanella xiamenensis BC01 growth and swarming motility
}

\author{
I-Son $\mathrm{Ng}^{1,2^{*}}$, Chukwuma Isaac Ndive ${ }^{1}$, Yunli Zhou ${ }^{1}$ and Xiaomin $\mathrm{Wu}^{1}$
}

\begin{abstract}
Background: Shewanella species belonging to dissimilatory metal bacteria were found to decolorize most textile dyes and had also attracted great interests in regard to bioremediation. However, studies have rarely been reported on Shewanella xiamenensis BC01, which was isolated as a biodecolorization and bioelectricity strain recently. In this study, the effect of cultivation conditions on S. xiamenensis BC01 was studied to explore how environmental conditions may influence $S$. xiamenensis growth and swarming motility.

Results: Shewanella xiamenensis BC01 grew over a wide range of $\mathrm{pH}(5.0-9.0)$ and mild temperatures $\left(25-42{ }^{\circ} \mathrm{C}\right)$. The optimal conditions for cell growth were using Luria-Bertani (LB) as medium with shaking at $150 \mathrm{rpm}, 37^{\circ} \mathrm{C}$, and $\mathrm{pH} 8.0$ which had been confirmed by shift $\mathrm{pH}$ and temperature. S. xiamenensis BC01 was able to resist $1 \mathrm{mM}$ concentrations of various metal ions, i.e., $\mathrm{Ca}^{2+}, \mathrm{Mg}^{2+}, \mathrm{Cu}^{2+}, \mathrm{Zn}^{2+}, \mathrm{Mn}^{2+}, \mathrm{Fe}^{3+}$, and $\mathrm{Al}^{3+}$, respectively. As shown in scanning electron microscopy (SEM) analyses, cell morphologies were slightly changed under metal stress. Swarming motility showed that the velocity ranking at $80 \mu \mathrm{M}$ and $1 \mathrm{mM}$ of metal was $\mathrm{Al}>\mathrm{Cr}>\mathrm{LB}>\mathrm{Zn}>\mathrm{Fe}>\mathrm{Cu}$ and $\mathrm{Mg}>\mathrm{Mn}>$ Ca, respectively.
\end{abstract}

Conclusions: This study evaluates the impact of cultivation methods and metal ions on the activity of S. xiamenensis BCO1 and provides an alternative to bioremediation of heavy metal-containing wastewaters by utilizing this strain.

Keywords: Shewanella xiamenensis; Optimization; Heavy metal; Swarming motility

\section{Background}

With the rise in industrialization and manufacturing activities, a lot of harmful substances are released daily into the atmosphere in large quantities. For example, environmental pollution, especially heavy metal pollution, represents an important problem due to the toxicity, and their accumulation throughout the food chain leads to serious ecological and health problems. However, many microorganisms demonstrated resistance to metals in water, soil, and industrial waste [1] and were intimately involved in metal biogeochemistry with a variety of processes determining mobility and therefore bioavailability [2]. Some microorganisms could enzymatically reduce a variety of metals in metabolic processes that are

\footnotetext{
* Correspondence: yswu@mail.ncku.edu.tw

'Department of Chemical and Biochemical Engineering, College of Chemistry and Chemical Engineering, Xiamen University, Xiamen 361005, China ${ }^{2}$ Department of Chemical Engineering, National Cheng Kung University, Tainan 70101, Taiwan
}

not related to metal assimilation, conserving energy to support growth by coupling the oxidation of simple organic acids and alcohols, $\mathrm{H}_{2}$, or aromatic compounds to the reduction of $\mathrm{Fe}(\mathrm{III})$ or $\mathrm{Mn}(\mathrm{IV})$ [3]. In particular, dissimilatory metal-reducing bacteria (DMRB) would reduce various metals and radionuclides, including sedimentabundant $\mathrm{Fe}(\mathrm{III})$ and $\mathrm{Mn}(\mathrm{III} / \mathrm{IV})$ and aqueous species of $\mathrm{U}(\mathrm{VI}), \mathrm{Cr}(\mathrm{VI}), \mathrm{Co}(\mathrm{III})$, and $\mathrm{Tc}(\mathrm{VII})$ [3-8].

Dissimilatory metal reduction was proposed to be an early form of microbial respiration [9]. As the reduction of metals by bacteria was generally coupled with the oxidation of organic matter $[9,10]$, the ability to reduce metals could be exploited not only for the bioreduction or immobilization of many toxic metals, including cobalt, chromium, uranium, and technetium, but also for the biotransformation of organic contaminants to benign products such as carbon dioxide [11, 12]. Several physicochemical methods existed for the treatment and remediation of metal-contaminated environments. The

\section{Springer}


conventional methods for heavy metal removal included chemical precipitation, chemical oxidation or reduction, ion exchange, filtration, electrochemical treatment, reverse osmosis, membrane technologies, and even evaporation recovery [13, 14]. These technologies, however, had some disadvantages such as the requirement for high energy and high facilities input. Another major disadvantage is the production of toxic chemical sludge, and its disposal or treatment becomes a costly affair and is not eco-friendly. Therefore, removal of toxic heavy metals to an environmentally safe level in a costeffective and environment-friendly manner assumes great importance.

Microorganisms were found in different habitats and had developed the capabilities to protect themselves from heavy metal toxicity by various mechanisms such as adsorption, uptake, methylation, oxidation, and reduction $[13,15,16]$. A number of metal-reducing bacteria have been isolated and characterized from a variety of habitats, and much work had focused on Shewanella and Geobacter spp. [17]. The genus Shewanella was first described two decades ago [18]. In general, shewanellae are members of the $\gamma$-proteobacteria that are gramnegative rods $2-3 \mu \mathrm{m}$ in length, $0.4-0.7 \mu \mathrm{m}$ in diameter, and motile by flagellum [19]. Shewanella species were widely distributed and had been isolated from various environments such as marine and freshwater, spoiled food, and oil field wastes and were capable of dissimilatory reduction of solid iron and manganese oxides [20]. Previous research revealed that the hallmark features of the members of this genus include unparalleled respiratory diversity and the capacity to thrive at low temperatures [21].

The strain used for this study, Shewanella xiamenensis BC01, is a newly isolated strain collected from sediment near Xiamen, China [15]. Phylogenetic analysis and identification of $16 \mathrm{~S}$ rRNA sequences of BC01 showed that it was similar to $S$. xiamenensis sp. nov. S4, a novel recently classified Shewanella species with distinct characteristics [22]. To date, there is no literature cited for swarming effect under metal stress by using $\mathrm{BC} 01$. The purpose of this study is to find out the effect of cultivation conditions on the growth, such as optimal $\mathrm{pH}$, temperature, and conditions. Moreover, cell morphology and swarming motility of S. xiamenensis $\mathrm{BC} 01$ under the response to different metal ions were further investigated and accelerated the application of this strain.

\section{Materials and method}

\section{Bacterial strain}

Shewanella xiamenensis $\mathrm{BC} 01$ has been deposited in the Bioresources Collection and Research Center (BCRC; Hsinchu, Taiwan) as BCRC80598 [15].

\section{Chemicals and reagents}

All chemical reagents used were of analytical grade without further purification. Stock solutions (100 mM) using deionized water $(10 \mathrm{ml})$ were prepared from the following metal salts: $\mathrm{AlCl}_{3} \cdot 6 \mathrm{H}_{2} \mathrm{O}, \mathrm{MnSO}_{4} \cdot \mathrm{H}_{2} \mathrm{O}, \mathrm{MgCl}_{2} \cdot 6 \mathrm{H}_{2} \mathrm{O}$, $\mathrm{FeCl}_{3} \cdot 6 \mathrm{H}_{2} \mathrm{O}, \mathrm{ZnSO}_{4} \cdot 7 \mathrm{H}_{2} \mathrm{O}, \mathrm{CuSO}_{4} \cdot 5 \mathrm{H}_{2} \mathrm{O}, \mathrm{AgNO}_{3}, \mathrm{CaCl}_{2}$ anhydrous (Sinopharm Chemical reagent Co., Ltd), and $\mathrm{K}_{2} \mathrm{Cr}_{2} \mathrm{O}_{7}$ (Sigma-Aldrich, USA). Other reagents used include Luria-Bertani (LB) and marine broth 2216, purchased from BD Difco (Difco, USA).

\section{Cultivation condition}

The isolated microorganism was grown on a LB agar plate at $30{ }^{\circ} \mathrm{C}$ and maintained at $4{ }^{\circ} \mathrm{C}$ for long storage. To culture S. xiamenensis BC01 (SXM), the cells inoculated from a loopful of seed colony were cultured overnight in $50 \mathrm{ml} \mathrm{LB}$ broth at $30{ }^{\circ} \mathrm{C}, 150 \mathrm{rpm}$ for $12 \mathrm{~h}$. Then, $0.5 \mathrm{ml}(1 \%, v / v)$ cells in the late log growth phase were transferred into $50 \mathrm{ml}$ fresh sterile LB media. Incubation proceeded for $24 \mathrm{~h}$ at $30{ }^{\circ} \mathrm{C}$ with shaking under aerobic conditions. The $\mathrm{pH}$, determined using a $\mathrm{pH}$ meter (Mettler-Toledo, Switzerland), and optical density at $600 \mathrm{~nm}\left(\mathrm{OD}_{600 \mathrm{~nm}}\right.$; SpectraMax M5, Molecular Device, USA) were monitored over the experimental time course. Cell concentrations were determined by extrapolating optical density readings at $600 \mathrm{~nm}$ to dry biomass values.

\section{Static and shaking cultures}

The same inoculation and cultivation procedure was done as described above. Fifty milliliters of LB broth was taken in sterilized 250-ml conical flasks and inoculated with $0.5 \mathrm{ml}$ logarithmic-phase culture of the bacterial isolate. The medium was then incubated for $24 \mathrm{~h}$ at $30{ }^{\circ} \mathrm{C}$ with orbital shaking $(150 \mathrm{rpm})$. For the static cultures, all tests were carried out in stationary mode at $30{ }^{\circ} \mathrm{C}$. Bacterial growth was monitored by measuring the $\mathrm{pH}$ and optical density at $600 \mathrm{~nm}$. Similar experiments were performed using marine broth 2216 (normally used for the cultivation of marine heterotropic bacteria), instead of LB, as the growth medium to determine the effect of culture media on the growth kinetics of the bacterium.

\section{Determination of optimum growth conditions}

For optimum growth of the bacterium, two parameters, i.e., temperature and $\mathrm{pH}$, were considered. Four sets of flasks were incubated at $25,30,37$, and $42{ }^{\circ} \mathrm{C}$, respectively. Incubation proceeded for $24 \mathrm{~h}$ at $30{ }^{\circ} \mathrm{C}$ with shaking under aerobic conditions. The $\mathrm{pH}$ was measured with a $\mathrm{pH}$ meter (Mettler-Toledo, Switzerland), and $\mathrm{OD}_{600 \mathrm{~nm}}$ was monitored in a spectrophotometer (SpectraMax M5, Molecular Device, USA) over the experimental time course. To determine the optimum $\mathrm{pH}, 250-\mathrm{ml}$ flasks, each containing $50 \mathrm{ml} \mathrm{LB}$, were prepared. The $\mathrm{pH}$ was adjusted to 5.0, 6.0, 7.0, 8.0, and 9.0, and then 

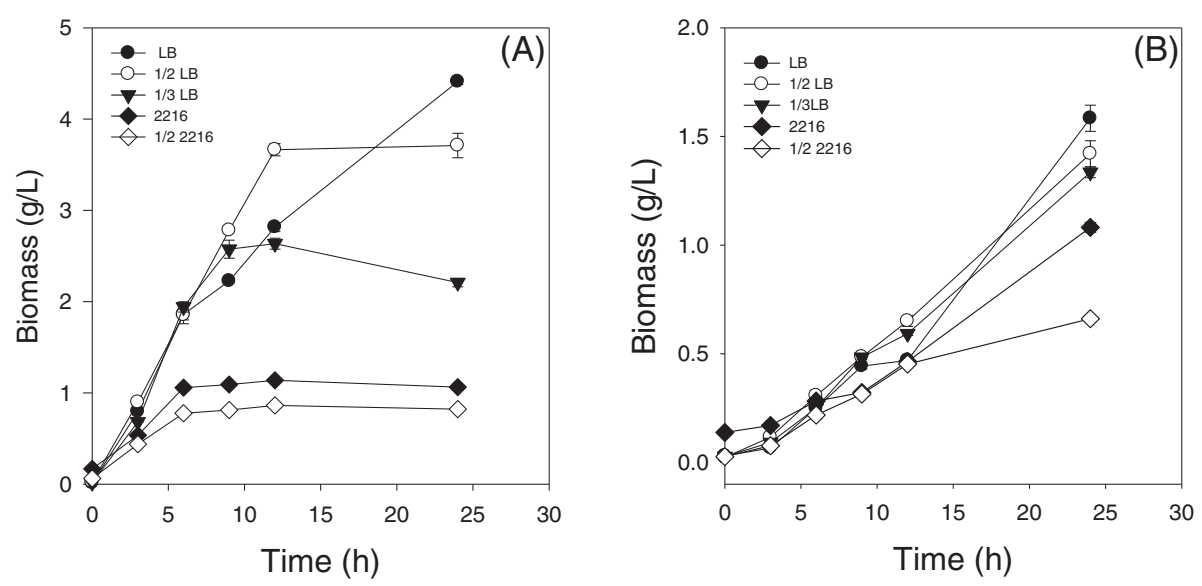

Fig. 1 Time course of biomass for SXM in different LB media: LB (black circle), one-half LB (white circle), one-third LB (black inverted triangle), 2216 (black diamond), and one-half 2216 (white diamond) under a shaking with $150 \mathrm{rpm}$ and $\mathbf{b}$ static condition at $30^{\circ} \mathrm{C}$

flasks were autoclaved $\left(121{ }^{\circ} \mathrm{C}\right.$ for $\left.20 \mathrm{~min}\right)$. These flasks were also inoculated as described above with the same culture conditions. The $\mathrm{pH}$ and growth of the bacteria were monitored periodically $(0,3,6,9,12$, and $24 \mathrm{~h})$ by measuring the OD at $600 \mathrm{~nm}$.

\section{Culture with addition of metal ions}

Resistance of SXM to nine metal ions, i.e., $\mathrm{Al}^{3+}, \mathrm{Mn}^{2+}$, $\mathrm{Mg}^{2+}, \mathrm{Fe}^{3+}, \mathrm{Zn}^{2+}, \mathrm{Cu}^{2+}, \mathrm{Ag}^{+}, \mathrm{Ca}^{2+}$, and $\mathrm{Cr}^{6+}$, was checked by addition of the respective metal salts in the LB medium. Metal ions were filter-sterilized $(0.2 \mu \mathrm{m})$ and added separately in the culture media. Stock solutions of $100 \mathrm{mM}$ concentration of the metals were prepared, except for $\mathrm{Cr}(4 \mathrm{mM})$. A final concentration of $1 \mathrm{mM}$ of all the metals except $\mathrm{Ag}(80 \mu \mathrm{M})$ and $\mathrm{Cr}(150 \mu \mathrm{M})$ was added in treated culture flasks containing $50 \mathrm{ml} \mathrm{LB}$ medium. Another flask without metal ions was used as the control. The culture flasks and metal ions were inoculated with $0.5 \mathrm{ml}$ overnight bacterial culture and incubated at $30{ }^{\circ} \mathrm{C}$ for $24 \mathrm{~h}$. Aliquots of culture were taken out in ovensterilized tubes, at regular intervals of $0,4,8,12$, and $24 \mathrm{~h}$, and growth was measured as optical density at $600 \mathrm{~nm}$.

\section{Swarming motility in LB agar plate with metal addition}

The LB media used in swarming assay with SXM consisted of a final concentration of the following metals: $\mathrm{Mg}, \mathrm{Ca}$, and $\mathrm{Mn}$ at $1 \mathrm{mM} ; \mathrm{Cu}, \mathrm{Zn}, \mathrm{Fe}$, and $\mathrm{Al}$ at $80 \mu \mathrm{M}$; and $\mathrm{Cr}$ at $150 \mu \mathrm{M}$. Another plate containing only LB agar was used as the control. The swarming motility assay was done as described elsewhere [23] except that LB was used as the culture medium instead of $2216 \mathrm{E}$ (marine agar). For the motility assay, $0.2 \mu \mathrm{l}$ from overnight culture grown at $30^{\circ} \mathrm{C}$ was placed on the swarming plates (LB medium with $0.7 \%$ agar). The agar media were airdried for 30-45 min before use. Swarming efficiency was dramatically improved when cells were inoculated onto the center of swarm plates [24]. All experiments were conducted in triplicates, and each set of plates was given the same amount of time to dry prior to inoculation. The plates were incubated at $30{ }^{\circ} \mathrm{C}$ for 7 days, and the motility was measured by examining the migration distance of the bacteria from one side to another side of the colony edge. Cultures were spotted onto each plate for 3 days, and the swarming distance was measured as the diameter of zone traveled by bacteria every day for 7 days. The plates were photographed at the third and seventh day to document differences between each plate.

\section{SEM analysis}

Whole amounts for scanning electron microscopy (SEM) were prepared by placing a small drop of a washed SXM suspension on a formvar-coated cover glass. Excess solution was wicked away using a piece of filter paper. Samples were fixed for $2 \mathrm{~h}$ by the addition of glutaraldehyde (final concentration of $2.5 \%$ ) and then dehydrated using a graded ethanol series and $100 \%$ tert-butyl alcohol. All samples were fixed, embedded, and sectioned under anaerobic conditions to avoid oxidations of redoxsensitive components. Whole amounts were examined using Hitachi S4800 (Hitachi, Japan) operating at a 10-kV accelerating voltage.

Table 1 The $\mathrm{pH}$ values of Shewanella xiamenensis BC01 in different culture media with shaking at $150 \mathrm{rpm}$ and $30^{\circ} \mathrm{C}$

\begin{tabular}{llcccc}
\hline Time (h) & LB & One-half LB & One-third LB & 2216 & One-half 2216 \\
\hline 0 & 7.22 & 7.18 & 7.19 & 7.53 & 7.53 \\
3 & 7.36 & 7.49 & 7.56 & 7.47 & 7.47 \\
6 & 7.64 & 7.74 & 7.92 & 7.61 & 7.78 \\
9 & 7.90 & 7.93 & 8.19 & 7.78 & 8.00 \\
12 & 8.32 & 8.46 & 8.41 & 7.91 & 8.30 \\
24 & 8.51 & 8.93 & 9.00 & 8.44 & 8.81 \\
\hline
\end{tabular}




\section{Results and discussions}

Effect of media and culture condition on growth of SXM To determine a suitable culture medium that supports rapid cell growth and good metal-reducing activity, two different media, marine broth 2216 and LB, were compared. The media were also diluted to one-half LB, onethird LB, and one-half 2216, to determine the effect of nutrient concentration on the biomass of the microorganism.
As shown in Fig. 1, SXM could grow and be cultivated in 2216 marine broth; however, the biomass only attained a low level $(\leq 1 \mathrm{~g} / \mathrm{l})$. In contrast, the LB medium showed the highest growth rate as the cell density was highest in the LB medium with $4.5 \mathrm{~g} / \mathrm{l}$ at $24 \mathrm{~h}$. At 9 and $12 \mathrm{~h}$, respectively, one-third LB and one-half LB reached the highest biomass values before the growth ceased or decreased. This phenomenon can be attributed to the fact that the
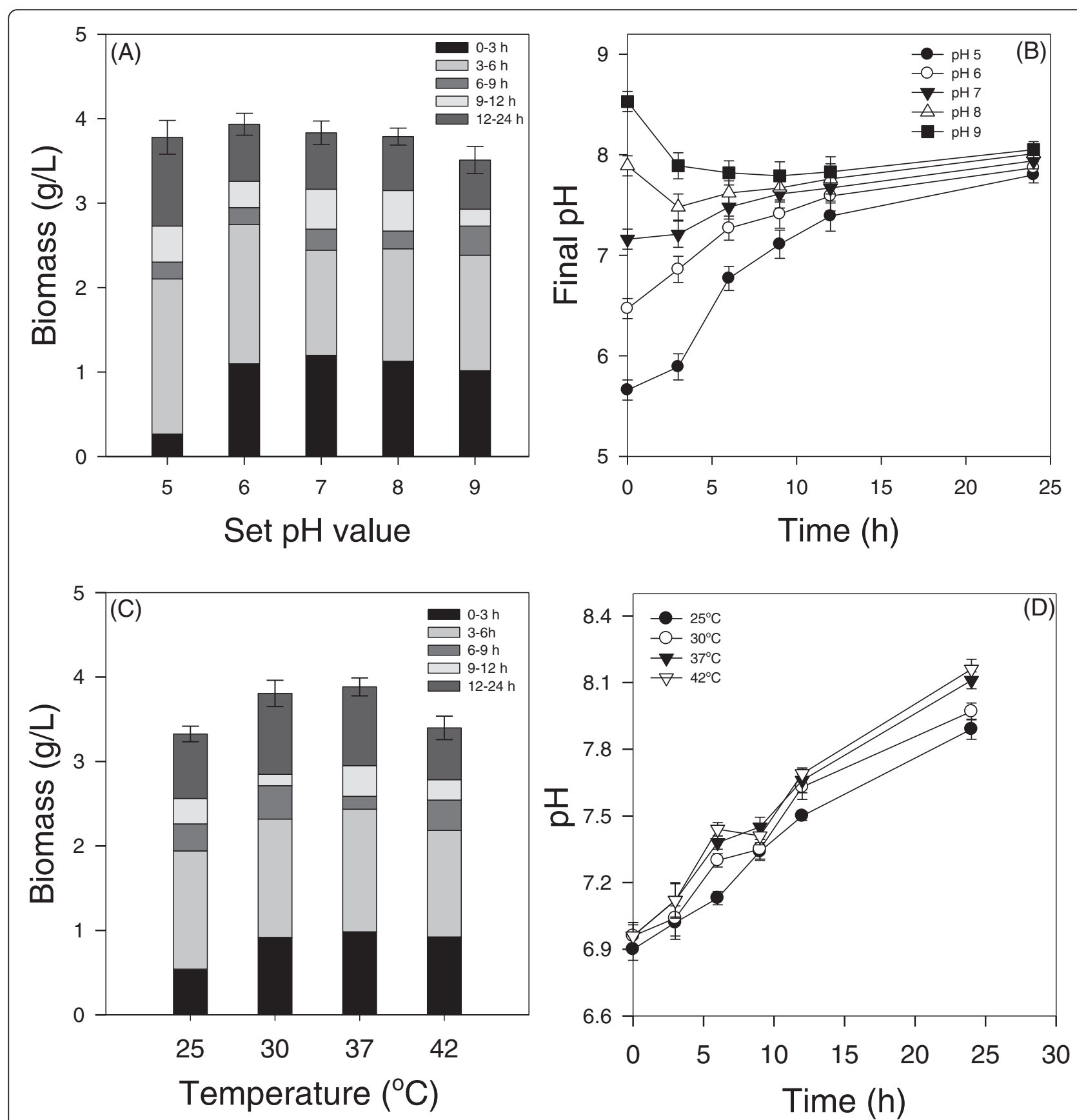

Fig. 2 The effect of $\mathrm{pH}$ and temperature on SXM growth in LB media with shaking at 150 rpm. Biomass stack bar (a) and time course of pH (b) for culture of SXM at different $\mathrm{pH}$ (pH 5 to $\mathrm{pH}$ 9). Biomass stack bar (c) and time course of pH (d) for culture of SXM at different temperature conditions of $25,30,37$, and $42{ }^{\circ} \mathrm{C}$, respectively 


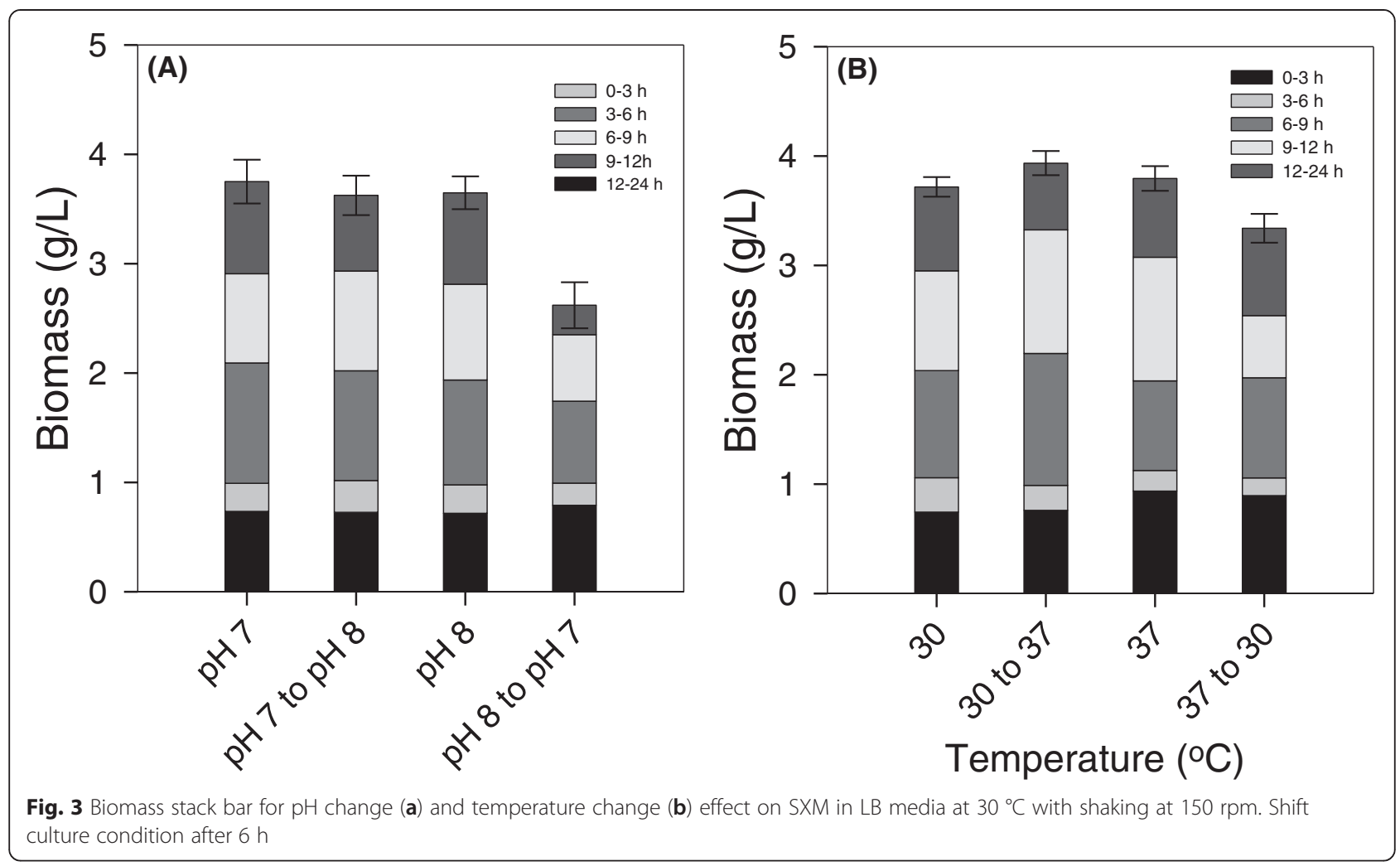

nutrients in the media have been depleted and thus the organism's growth impeded. Examination of SXM growth is important for bioremediation applications, since heavy metal reduction rates have been shown to be directly related to total biomass [25].
The growth curve pattern under static conditions (Fig. 1b) was significantly different from that of shaking. Under shaking conditions, SXM attained more biomass yield compared to the yield under static conditions. The $\mathrm{pH}$ values of SXM in different media under shaking
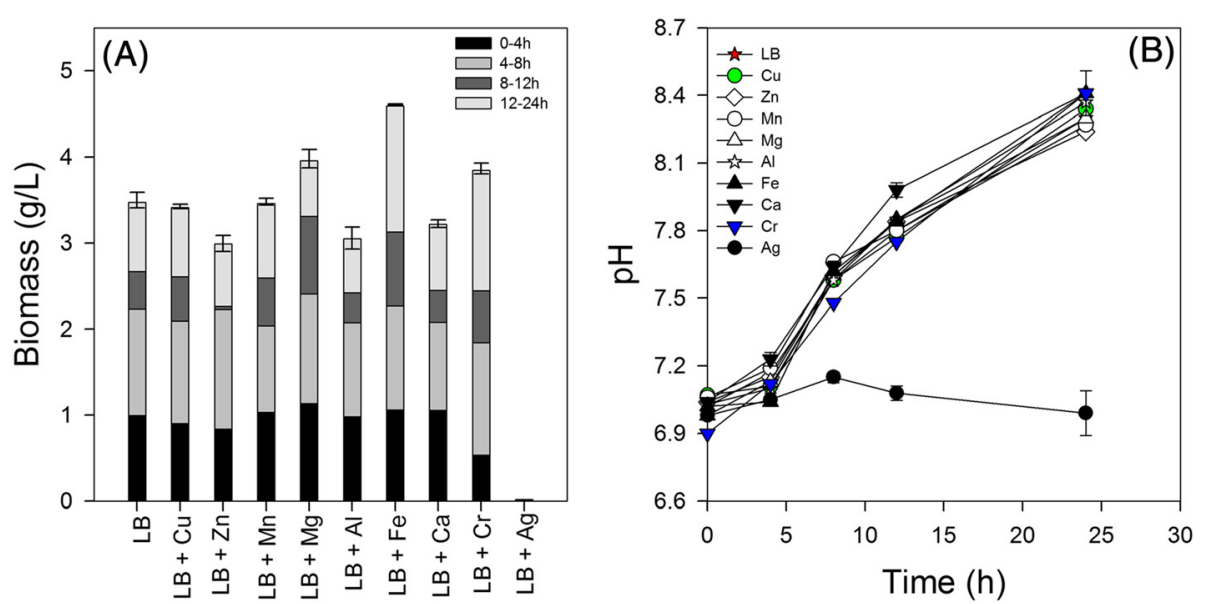

Fig. 4 Effect of metal ions on the growth of SXM in LB media containing different concentrations of heavy metal ions at $30{ }^{\circ} \mathrm{C}$ and 150 rpm. Biomass stack bar (a) and pH changes (b). Except metal ions of $\mathrm{Cr}$ and $\mathrm{Ag}$ which are at a concentration of $80 \mu \mathrm{M}$, other metals are at concentrations of $1 \mathrm{mM}$ 
conditions are shown in Table 1. From the table, it can be seen that the $\mathrm{pH}$ measurement under shaking conditions showed consistency with time, increasing with concomitant increase in cultivation time. This showed that increase in biomass might be correlated with a corresponding increase in $\mathrm{pH}$. On the other hand, $\mathrm{pH}$ under static conditions (data not shown) showed a different pattern, decreasing at first before a slow, gradual increase occurs. This can

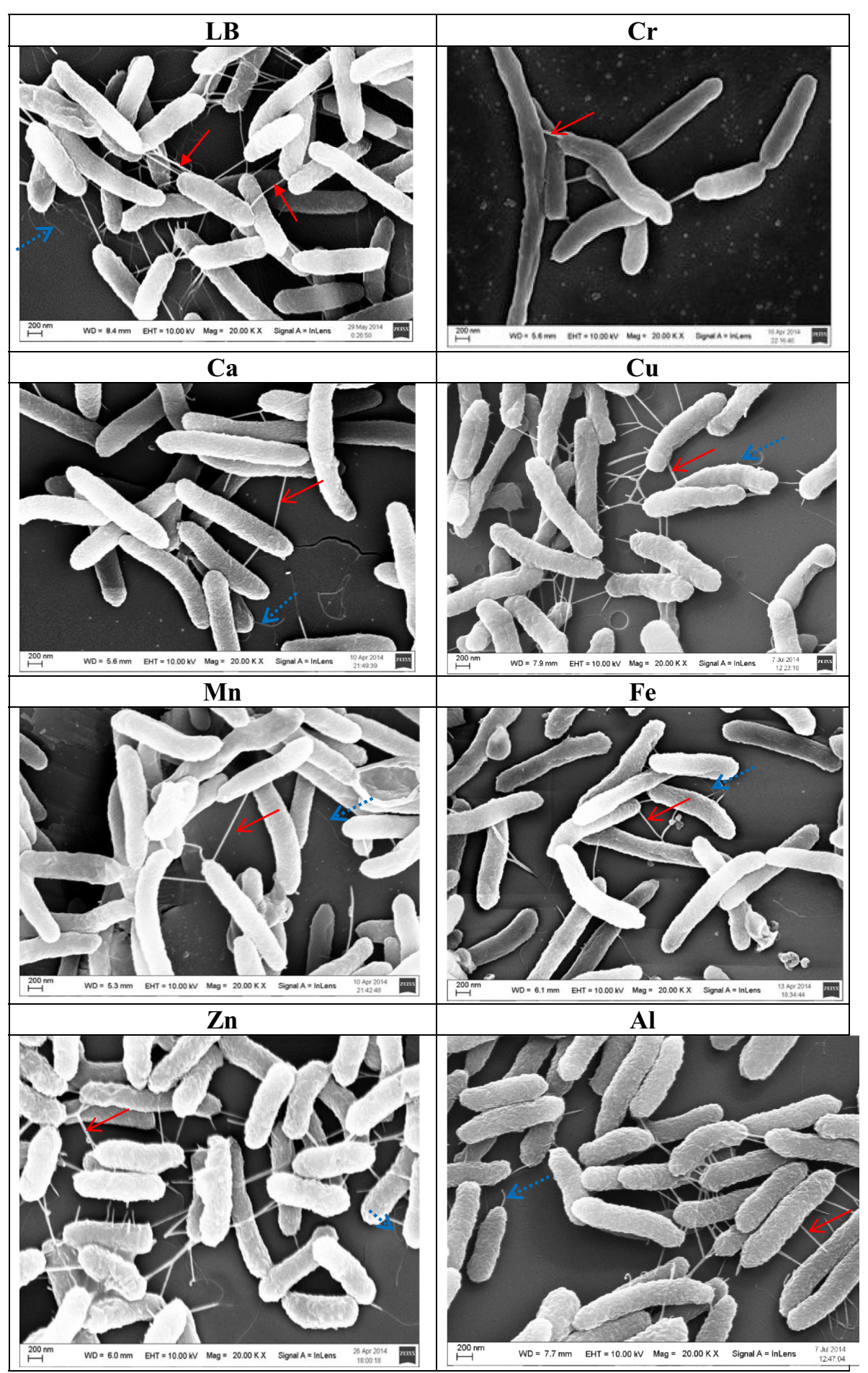

Fig. 5 Scanning electron microscopy (SEM) analysis of SXM cultured in LB medium with different metal ions. All cells were grown for $24 \mathrm{~h}$ at $30{ }^{\circ} \mathrm{C}$. SXM produced flagellum (indicated by blue dot arrows), and nanowires (indicated by red arrows) were observed 
be attributed to the fact that under static cultivation technique, essential parameters directly impacting organism physiology are poorly described. These parameters, which include nutrient availability, specific growth rate, and poor mixing, lead to cultural/environmental heterogeneity [26]. The increase in optical density measured during the course of the experiment under shaking conditions reflected the metabolic variability between cultures and may result from increased variability in the mass transfer kinetics in poorly mixed cultures compared to shake flask. Shaking, therefore, results in an optimal mass transfer and more consistent metabolic activities within cultures.

\section{Optimum $\mathrm{pH}$ and temperature conditions}

Figure 2a shows the effect of $\mathrm{pH}$ on the growth of SXM. It was observed that growth occurred at a $\mathrm{pH}$ range of 5.09.0, but an optimum growth was observed at pH 8.0. SXM exhibited a slight increase in growth over the temperature between 25 and $37{ }^{\circ} \mathrm{C}$ and with maximum at $37{ }^{\circ} \mathrm{C}$ (Fig. 2c). From Fig. 2b, d, the pH of SXM showed a trend towards basic condition (i.e., $\mathrm{pH}$ 8.0) indicative of its marine habitat. However, extreme $\mathrm{pH}$ (9.0) restricted the bacterial growth.

Figure $3 \mathrm{a}$ shows the effect of $\mathrm{pH}$ fluctuations on biomass. Here, the initial $\mathrm{pH}$ values of 7.0 and 8.0 were, at $6 \mathrm{~h}$, changed from 7.0 to 8.0 and vice versa. A pH decrease from 8.0 to 7.0 had a negative effect on SXM biomass whereas an increase from 7.0 to 8.0 led to no changes on biomass yield, showing that $\mathrm{pH} 8.0$ is the optimum $\mathrm{pH}$.

As shown in Fig. 3b, the temperatures were changed from 30 to $37^{\circ} \mathrm{C}$ and vice versa at $6 \mathrm{~h}$. Even though SXM could grow well at both temperatures, the biomass increased exponentially after a temperature increase from 30 to $37{ }^{\circ} \mathrm{C}$. In contrast, a reduction from 37 to $30{ }^{\circ} \mathrm{C}$
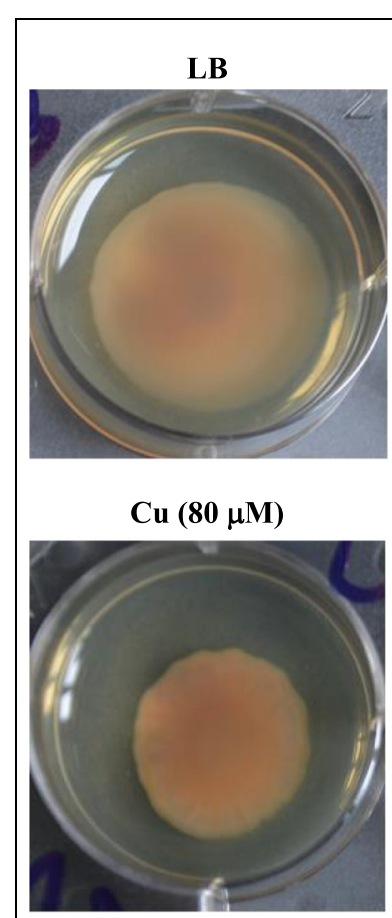

Mn (1 mM)

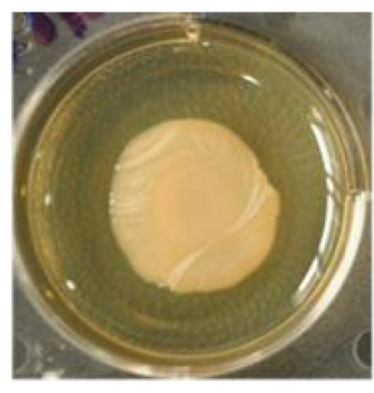

Fe $(80 \mu M)$

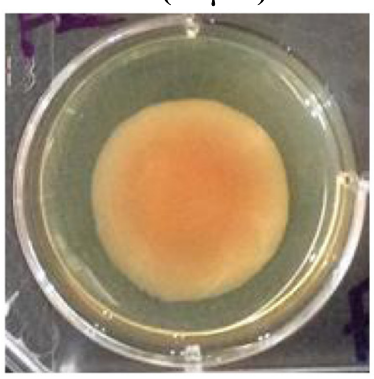

$\operatorname{Zn}(80 \mu \mathrm{M})$

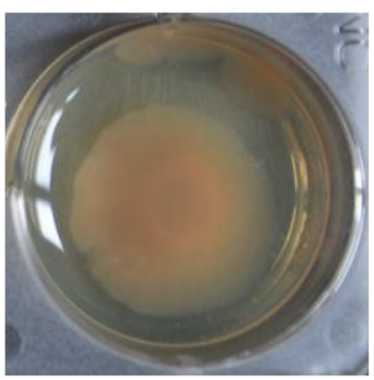

$\operatorname{Mg}(1 \mathrm{mM})$

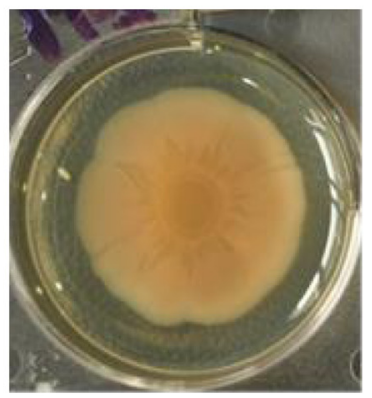

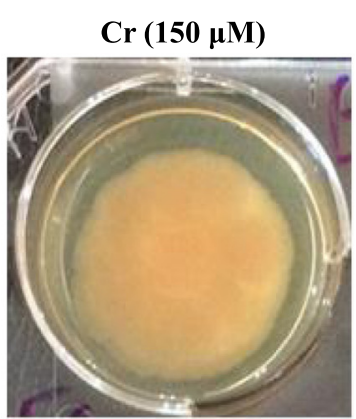

Al $(80 \mu \mathrm{M})$

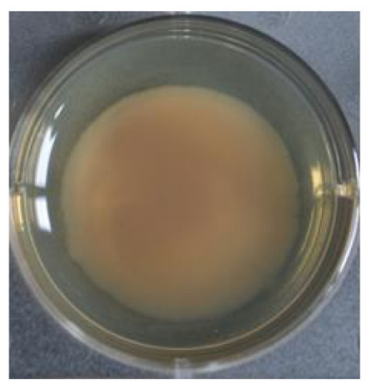

Ca (1 mM)

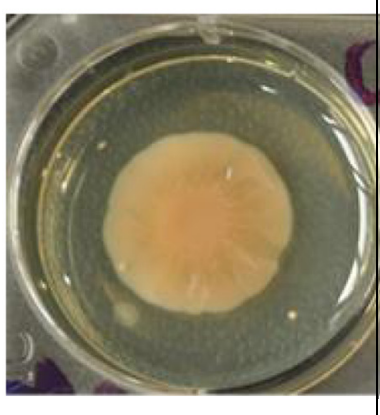

Fig. 6 Swarming motility of SXM after 7 days of cultivation in LB agar supplemented with different metal ions at $30^{\circ} \mathrm{C}$ and $150 \mathrm{rpm}$ 
showed a reduction in biomass yield. This confirms the fact that SXM attains the highest possible biomass at $37^{\circ} \mathrm{C}$.

\section{Resistance to heavy metal ions}

SXM was tested for its resistance to various metals, such as $\mathrm{Ca}, \mathrm{Mg}, \mathrm{Mn}, \mathrm{Cu}, \mathrm{Zn}, \mathrm{Al}, \mathrm{Ag}, \mathrm{Cr}$, and $\mathrm{Fe}$. Relative growth of the strain in different metal-containing media is shown in Fig. 4. It was evident that SXM was resistant to all the metals except Ag. It showed that the strain was incapable of growing in the presence of $\mathrm{Ag}$ as it was significantly inhibitory for growth. SXM also showed that maximum resistance against $1 \mathrm{mM}$ of metal ion with regard to the biomass was $\mathrm{Fe}^{3+}>\mathrm{Mg}^{2+}>\mathrm{Mn}^{2+}>$ $\mathrm{Cu}^{2+}>\mathrm{Ca}^{2+}>\mathrm{Al}^{3+}>\mathrm{Zn}^{2+}$, respectively.

Inhibition of microbes by heavy metals has been reported earlier. Enterobacter cloacae was completely inhibited by low concentrations of $\mathrm{Hg}^{2+}(1 \mu \mathrm{M}), \mathrm{Cu}^{2+}(390 \mu \mathrm{M}), \mathrm{Mn}^{2+}$ $(480 \mu \mathrm{M})$, and $\mathrm{Zn}^{2+}(0.3 \mu \mathrm{M})$ [27]. Wang et al. [28] showed that at high concentrations, $\operatorname{Ag}(\mathrm{I})$ can penetrate the cell and potentially impact on several areas of metabolism, most notably lipid metabolism and membrane integrity in Shewanella oneidensis. Heavy metal uptake processes by biological cells are generally referred to as biosorption and include both passive adsorption of heavy metals to the cell walls and metabolically mediated uptake. This uptake of heavy metals by live cells has become one of the most attractive means for bioremediation of industrial wastes and other metal-polluted environments [16]. Tolerance to other metals has an added advantage of withstanding the presence of different metallic ions while performing the desired activity. Therefore, we suggest that metal tolerance was due to bioaccumulation of heavy metals by the bacterium.

The SEM image of SXM revealed that it had a long rod shape with a diameter of $1.5-2.0 \mu \mathrm{m}$, was motile by means of a single polar flagellum (indicated by blue dot arrows), and had nanowires (indicated by red arrows) cross-linked between the cell systems (Fig. 5). Also, the morphology of SXM on LB agar plate showed that plum-red pigments are secreted from the cell (Fig. 6). However, the cell morphologies varied under different growth conditions and metal stress. In metals like $\mathrm{Cu}, \mathrm{Cr}$, and $\mathrm{Ca}$, the cells were narrower, slender, and elongated, with less condensed and fewer cells. Similar morphologies were observed in cells grown in $\mathrm{Mn}$ and $\mathrm{Fe}$, as they showed an aggregation of slender, elongated cells. Zn showed shorter but robust cells.

Previous experiments report that S. oneidensis MR-1 can utilize extracellular nanowires of mineral forms as the electron acceptor for dissimilatory metal reduction $[29,30]$. Moreover, bacterial nanowires present important and logical implications for enzymatic reduction of solid-phase iron and manganese oxides by DMRB, such as Shewanella and Geobacter. Bacterial nanowires are extracellular appendages that have been suggested as pathways for electron transport in phylogenetically diverse microorganisms. In this study, pilus-like appendages are produced by SXM and they can represent nanowires.

\section{Effects of metal ions on the swarming motility}

The motility of SXM was monitored for 7 days at $30{ }^{\circ} \mathrm{C}$. Various metals with different concentrations were tested for their inhibition of or effect on SXM swarming (Fig. 6). The growth curve of external diameter and swarming distance were calculated and shown in Fig. 7.
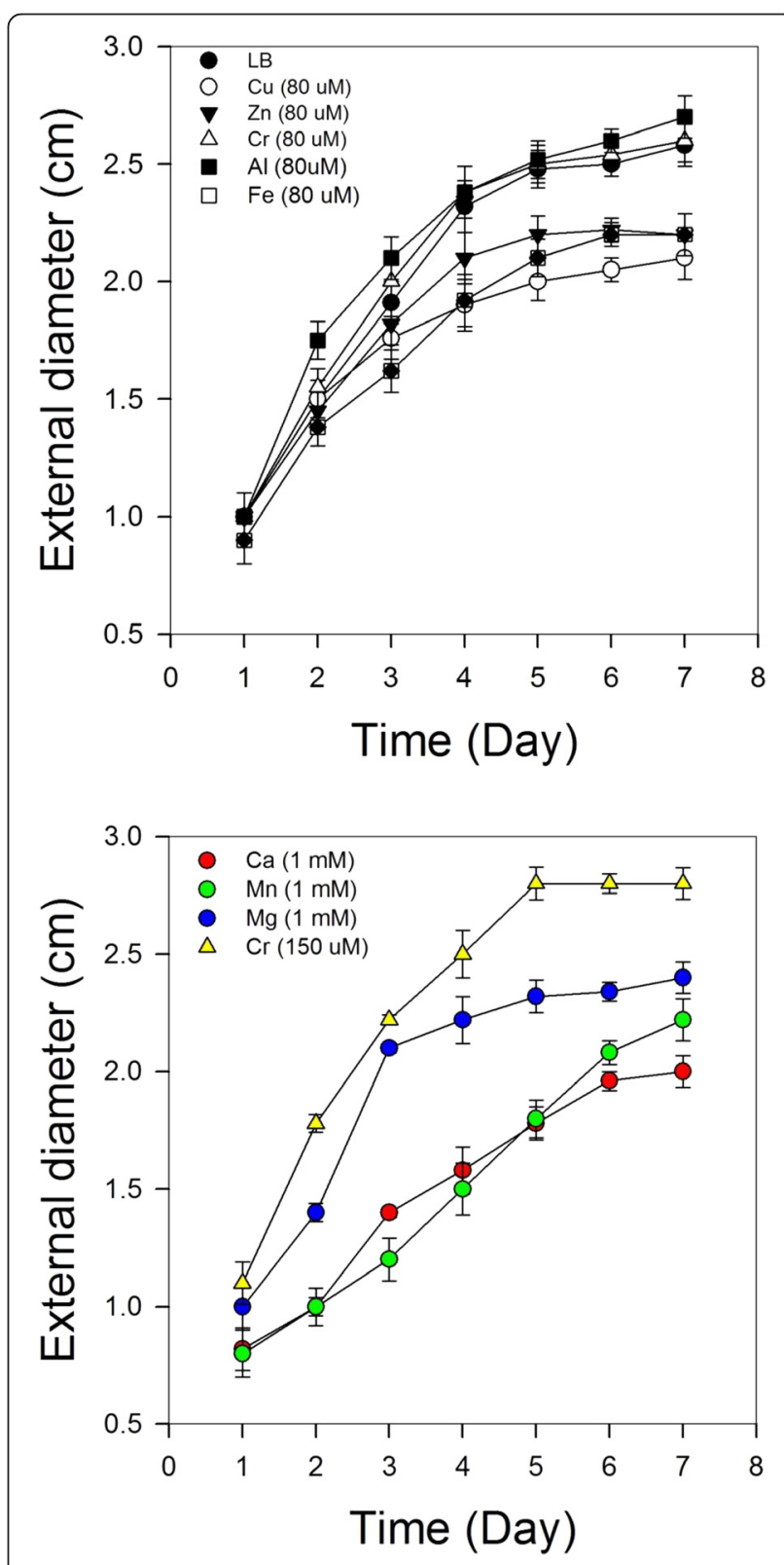

Fig. 7 Growth curve of external diameter and swarming distance of SXM in LB agar containing (upper) $80 \mu \mathrm{M}$ metal cations and (lower) $1 \mathrm{mM}$ metals, except for $\mathrm{Cr}$ which is $150 \mu \mathrm{M}$ 
SXM showed a strong tendency to engage in swarming behavior, even at the $150 \mu \mathrm{M}$ of $\mathrm{Cr}$ in the LB agar plate. Results of the experiments showed significant differences in swarming behavior between various metals, including differences not only in the size of the swarm zone but also in the tendril formation and the behavior at the edge of the swarm zone (Fig. 6).

SXM with Al exhibited the most swarming, followed by Cr. SXM with Mn showed the least swarming after the first day (data not shown), moving only a few inches beyond the point of inoculation after 7 days (Fig. 6). Interestingly, most of the metals, especially $\mathrm{Cu}, \mathrm{Ca}, \mathrm{Fe}$, and $\mathrm{Zn}$, showed a reduction in swarming behavior after 4 days, while at final concentrations of $1 \mathrm{mM}$ of $\mathrm{Cu}, \mathrm{Zn}$, $\mathrm{Fe}$, and $\mathrm{Al}$ on SXM, it displayed no swarming activity on the agar plate (data not shown). Swarming is a powerful means of rapidly colonizing nutrient-rich environments, facilitating colony spread, and accelerating biomass production [31]. Cell density, surface contact, and physiological signals all provide critical stimuli, and close cell alignment and the production of secreted migration factors facilitate mass translocation [31]. Another study had shown that different bacteria exhibit swimming or swarming or both types of motility [32], in which S. oneidensis MR-1 displayed swimming in complex media but no swarming across surfaces was observed. Swarming is different from swimming which is dependent only on flagella and occurs in a liquid medium or solid medium with lower concentrations of agar [33]. Swarming, however, is a surface phenomenon. In addition to flagella, swarmer cells require an increased production of certain extracellular components (known as wetting agents) that reduce surface friction and enable the smooth migration of a group of cells on viscous surfaces [34]. Swarming is a multicellular type of motility and is considered as a model of bacterial social behavior and had been shown to be associated with virulence and resistance to antibiotics in some species.

Metals could inhibit the swarming of bacteria either by reducing the wetness of the colony or by suppressing the activity of the wetting agent or rhamnolipid biosynthetic pathway. Members of the Shewanella genus are mostly isolated from seas and sediments and grow at low temperatures [22]; thus, swarming is most likely the dominant motility pattern of cells in such habitats. Our hypotheses are that variations in swarming may be directly related to rhamnolipid production and also swarming defects may be due to inadequate wetness required for the swarming movement under different metals.

\section{Conclusions}

Shewanella xiamenensis $\mathrm{BC} 01$ can grow over a wide range of $\mathrm{pH}$ and mild temperatures, which is an adaptive mechanism considering the fact that aquatic environments are warmed either naturally or by power plant effluents and other heated wastes. Many studies have shown that Shewanella has the ability to use various terminal electron acceptors, allowing them to survive in extreme and harsh environments such as the absence of oxygen or very low temperatures. The results indicate that $S$. xiamenensis BC01 activity may be sensitive to environmental factors present in the culture medium. Also, in its interaction with metals, it can be assumed that $S$. xiamenensis $\mathrm{BC} 01$ has the capability of accumulating and transforming these metals to nontoxic forms. Thus, this strain has potential in bioremediation and detoxification of heavy metals in industrial wastewaters.

\section{Abbreviations}

DMRB: dissimilatory metal-reducing bacteria; LB: Luria-Bertani; SEM: scanning electron microscopy; SXM: Shewanella xiamenensis BC01.

\section{Competing interests}

The authors declare that they have no competing interests.

\section{Authors' contributions}

IN designed the experiments and wrote the manuscript. $\mathrm{NCl}$ performed all the experimental works. $X W$ and $Y Z$ interpreted the results. All authors read and approved the final manuscript.

\section{Acknowledgements}

The authors are grateful to the National Natural Science Foundation of China (21206141), the National High-Tech R\&D Program of China (2014AA021701), and the Ministry of Science and Technology, Taiwan (MOST 103-2218-E-006-027-MY2).

Received: 6 April 2015 Accepted: 1 June 2015

Published online: 27 June 2015

\section{References}

1. Bruins MR, Kapil S, Oehme FW (2000) Microbial resistance to metals in the environment. Ecotox Environ Safe 45(3):198-207

2. Gadd GM (2004) Microbial influence on metal mobility and application for bioremediation. Geoderma 122:109-119

3. Lovley DR (1993) Dissimilatory metal reduction. Annu Rev Microbiol 47:263-290

4. Gorby YA, Lovley DR (1992) Enzymic uranium precipitation. Environ Sci Technol 26(1):205-207

5. Gorby YA, Caccavo F, Bolton H (1998) Microbial reduction of cobalt III EDTAin the presence and absence of manganese(IV) oxide. Environ Sci Technol 32(2):244-250

6. Liu C, Gorby YA, Zachara JM, Fredrickson JK, Brown CF (2002) Reduction kinetics of Fe(III), $\mathrm{Co}(\mathrm{III}), \mathrm{U}(\mathrm{VI}), \mathrm{Cr}(\mathrm{VI})$, and $\mathrm{TC}(\mathrm{VII})$ in cultures of dissimilatory metal-reducing bacteria. Biotechnol Bioeng 80(6):637-649

7. Nealson KH, Saffarini D (1994) Iron and manganese in anaerobic respiration: environmental significance, physiology, and regulation. Annu Rev Microbiol 48:311-343

8. Wildung RE, Gorby YA, Krupka KM, Hess NJ, Li SW, Plymale AE (2000) Effect of electron donor and solution chemistry on products of dissimilatory reduction of technetium by Shewanella putrefaciens. Appl Environ Microbiol 66(6):2451-2460

9. Liu SV, Zhou J, Zhang C, Cole DR, Gajdarziska-Josifovska M, Phelps TJ (1997) Thermophilic Fe(III)-reducing bacteria from the deep subsurface: the evolutionary implications. Science 277(5329):1106-1109

10. Roh Y, Liu SV, Li G, Huang H, Phelps TJ, Zhou J (2002) Isolation and characterization of metal-reducing thermoanaerobacter strains from deep subsurface environments of the Piceance Basin, Colorado. Appl Environ Microbiol 68(12):6013-20

11. Fredrickson JK, Zachara JM, Kennedy DW, Dong H, Onstott TC, Hinman NW, Li S (1998) Biogenic iron mineralization accompanying the dissimilatory reduction of hydrous ferric oxide by a groundwater bacterium. Geochim Cosmochim Ac 62:3239-3257

12. Roh Y, Gao H, Vali H, Kennedy DW, Yang ZK, Gao W, Dohnalkova AC, Stapleton RD, Moon JW, Phelps TJ, Fredrickson JK, Zhou J (2006) Metal 
reduction and iron biomineralization by a psychrotolerant Fe(III)-reducing bacterium, Shewanella sp. strain PV-4. Appl Environ Microb 72(5):3236-3244

13. Ahluwalia SS, Goyal D (2007) Microbial and plant derived biomass for removal of heavy metals from wastewater. Bioresour Technol 98:2243-2257

14. Babel S, Kurniawan TA (2003) Low-cost adsorbent for heavy metal uptake from contaminated water a review. J Hazard Mater 397:219-243

15. Ng IS, Chen T, Lin R, Zhang X, Ni C, Sun D (2014) Decolorization of textile azo dye and Congo red by an isolated strain of the dissimilatory manganesereducing bacterium Shewanella xiamenensis BC01. Appl Microbiol Biotechnol 98(5):2297-2308

16. Venil CK, Mohan V, Lakshmanaperumalsamy P, Yerima MB (2011) Optimization of chromium removal by the indigenous bacterium Bacillus spp. REP02 using the response surface methodology, ISRN Microbiol., p 951694

17. Lovley DR, Holmes DE, Nevin KP (2004) Dissimilatory Fe(III) and Mn(IV) reduction. Adv Microbiol Physiol 49:219-286

18. MacDonell MT, Colwell RR (1985) Phylogeny of the Vibrionaceae, and recommendation for two new genera, Listonella and Shewanella. Syst Appl Microbiol 6:171-182

19. Venkateswaran $K$, Moser D, Dollhopf M, Lies D, Saffarini D, MacGregor B, Ringelberg D, White D, Nishijima M, Sano H, Burghardt J, Stackebrandt E, Nealson KH (1999) Polyphasic taxonomy of the genus Shewanella and description of Shewanella oneidensis sp. nov. Int J Syst Bacteriol 49:705-724

20. Nealson KH, Scott J (2006) Ecophysiology of the genus Shewanella. In the Prokaryotes: a Handbook on the Biology of Bacteria 6:1133-1151

21. Hau HH, Gralnick JA (2007) Ecology and biotechnology of the genus Shewanella. Annu Rev Microbiol 61(1):237-258

22. Huang J, Sun B, Zhang X (2010) Shewanella xiamenensis sp. nov., isolated from coastal sea sediment. Int J Syst Evol Microbiol 60:1585-1589

23. Jian H, Xiao X, Wang F (2013) Role of filamentous phage SW1 in regulating the lateral flagella of Shewanella piezotolerans strain WP3 at low temperatures. Appl Environ Microbiol 79(22):7101-7109

24. Burkart M, Toguchi A, Harshey RM (1998) The chemotaxis system, but not chemotaxis, is essential for swarming motility in Escherichia coli. Proc Natl Acad Sci USA 95(5):2568-2573

25. Middleton S, Latmani R, Mackey M, Ellisman M, Tebo B, Criddle C (2003) Cometabolism of $\mathrm{Cr}(\mathrm{VI})$ by Shewanella oneidensis MR-1 produces cell-associated reduced chromium and inhibits growth. Biotechnol Bioeng 83:627-637

26. Elias DA, Tollaksen SL, Kennedy DW, Mottaz HM, Giometti CS, McLean JS, Hill EA, Pinchuk GE, Lipton MS, Fredrickson JK, Gorby YA (2008) The influence of cultivation methods on Shewanella oneidensis physiology and proteome expression. Arch Microbiol 189(4):313-324

27. Hardoyo JK, Ohtake H (1991) Effects of heavy metal cations on chromate reduction by Enterobacter cloacae strain HO1.J Gen Appl Microbiol 37:519-522

28. Wang $H$, Law $N$, Pearson $G$, van Dongen BE, Jarvis RM, Goodacre R, Lloyd JR (2010) Impact of silver(I) on the metabolism of Shewanella oneidensis. J Bacteriol 192(4):1143-1150

29. El-Naggar MY, Wanger G, Leung KM, Yuzvinsky TD, Southam G, Yang J, Lau M, Nealson KH, Gorby YA (2010) Electrical transport along bacterial nanowires from Shewanella oneidensis MR-1. Proc Natl Acad Sci USA 107:18127-18131

30. Gorby YA, Yanina S, Mclean JS, Rosso KM, Moyles D, Dohnalkova A, Beveridge TJ, Chang IS, Kim BH, Kim KS, Culley DE, Reed SB, Romine MF, Saffarini DA, Hill EA, Shi L, Elias DA, Kennedy DW, Pinchuk G, Watanabe K, Ishii S, Logan B, Nealson KH, Fredrickson JK (2006) Electrically conductive bacterial nanowires produced by Shewanella oneidensis strain MR-1 and other microorganisms. Proc Natl Acad Sci USA 103(30):11358-11363

31. Fraser GM, Hughes C (1999) Swarming motility. Curr Opin Microbiol 2:630-635

32. Paulick A, Koerdt A, Lassak J, Huntley S, Wilms I, Narberhaus F, Thormann KM (2009) Two different stator systems drive a single polar flagellum in Shewanella oneidensis MR-1. Mol Microbiol 71(4):836-850

33. Inoue T, Shingaki R, Fukui K (2008) Inhibition of swarming motility of Pseudomonas aeruginosa by branched-chain fatty acids. FEMS Microbiol Lett 281(1):81-86

34. Harshey RM (2003) Bacterial motility on a surface: many ways to a common goal. Annu Rev Microbiol 57:249-273

\section{Submit your manuscript to a SpringerOpen ${ }^{\circ}$ journal and benefit from:}

- Convenient online submission

- Rigorous peer review

- Immediate publication on acceptance

- Open access: articles freely available online

- High visibility within the field

- Retaining the copyright to your article

Submit your next manuscript at $>$ springeropen.com 